\title{
PROGRAM OF PURPOSEFUL DEVELOPMENT OF ORGANIZATIONAL ABILITIES OF STUDENTS \\ AND CADETS OF THE NATIONAL ACADEMY OF THE STATE BORDER GUARD SERVICE OF UKRAINE
}

\section{Olena Volobuieva}

\section{INTRODUCTION}

Nowadays it is of vital importance to improve the system of professional training of the personnel of the State Border Guard service of Ukraine (SBGSU) particularly it is essential to develop the organizational abilities of the future border guard officers who are to organize the professional activities of the subordinates on combating international terrorism, illegal migration, human trafficking, drugs dealing, weapons smuggling and other transnational crimes on the state border of Ukraine. The results of the analysis of the problem of the border guard officers' professional competence indicate that the structure of their organizational abilities is determined by the specificity of their professional activity. The main functional duties of a border guard officer are the strict organization, support, control of the activities on protection and defense of the state border of Ukraine and also the proper moral and psychological support of the professional activity of all categories of the personnel.

\section{Substantiation of the Program}

Taking into our account the fact that the proper level of the organizational abilities give the border guard officer the opportunity to carry out the management activity on border protection effectively and the results of our analysis we have worked out the special program on the purposeful development of organizational abilities of students and cadets of the National Academy of the State border guard service of Ukraine (NASBGSU) where the professional training of all the categories of the personnel is carried out. While working out the program we have taking into our consideration the results) of: 1) the of the anonymous questionnaire on the organizational abilities of the 
border guard officers as for their understanding, evaluation, meaning and structure in the context of the professional duties in the special and extreme activity conditions and 2) the state of the formation and development of the organizational abilities of the border guard officers according to the evidence the vectors of the rise in the level of their formation (at the first stage of professionalization) and development (at the further stages of professionalization) in the conditions of the higher military educational establishment ${ }^{1}$ (Volobuieva, 2018).

\section{Analysis of border guard officers' professional activity components}

Having analyzed the psychological peculiarities of the border guards professional activity which is performed in the specific and extreme conditions we have determined the components of such activity. They are the following: the cognitive (gnostic), constructive, organizational and communicative components. Each component is typical of performing the certain functions and responsibilities. Let's analyze these components in more details.

1. Gnostic component (referred to in Greek as cognition), this component is also called a research component) - the system of some knowledge, skills and habits of border guard officer. This component is considered to be the basis of individual's professional activity, as well as the certain qualities of the cognitive activity that influence its effectiveness): 1) the research of the subjects of the very activity, the process peculiarities of the professional activity and the results of this activity; 2) study and monitoring of individual, age and gender characteristics of the subordinate personnel for effective mobilization of their activities; 3) the reflection of the peculiarities, specificity and results of an individual professional activity.

1 Volobuieva O. F. (2018). Pro rezultaty anonimnogo opituvanny schodo organizatorskih zdibnostey ofitseriv-prikordonnikiv [About the Results of the Anonymous Questionnaire on the Organizational Abilities of the Border Guard Officers]. Zbirnik naukovih prats Natsionalnoyi akademiyi Derzhavnoyi prikordonnoyi sluzhbi Ukrayini. Seriya: psihologichni nauki - Collection of the Scientific Works of the National Academy of the State Border Guard Service of Ukraine. Series: Psychological Sciences. Hmelnitskiy: NASBGSU Publ. 1(9). 68-85 [in Ukrainian]. 
2. Constructive component - the authority and leadership function: 1) collecting and analyzing some information on the peculiarities and specifics of performing professional activities in the area of responsibility; 2) the ability to overcome stress as well as conflicts and to reach an agreement; 3 ) organization of group activities of the unit as a small group with external status in general and as a separate entity in particular; 4) the ability to develop a unit and consolidate it; 5) planning of a person's professional activity as the leader of the unit, as well as processes of his/ her individual development.

3. Organizational component: 1) the various types of organizational and managerial activity; 2) the individual professional activity and behavior; 3) informing the subjects of the professional activity; 4) organization, support, control on the basis of individual demand and responsibility; 5) organization of activities of subordinate personnel using the up-to-date methods of the psychological influence on an individual in the conditions of considerable psychological stress $^{2}$ (Willis Dan, 2014).

4. Communicative component: 1) the ability to communicate and exchange some information; 2) communication flexibility; 3) establishing the optimal relations with the professional activity subjects; 4) problem-solving ability and the ability to change the nature of interpersonal relationships in the conflict situations.

All the components of the border guard officers' professional activity are interrelated and implemented into the consolidated purposeful activity. The organizational activity is of vital importance in the border guard officer's professional activity. This very type of activity plays the key role in the organizational system "border guard officer - subordinate personnel". Moreover, it is the organizational activity that is the most important type of activity which integrates the various aspects of the specific professional activity of all the staff categories of the State Border Guard Service of Ukraine, because there is the organizational component in each of its sub-structures.

Let's consider this aspect in more details. The professional interaction "border guard officer-subordinate personnel" implies joint

2 Willis Dan (2014). Bulletproof Spirit. The First Responder's Essential Resource for Protecting and Healing Mind and Heart. New World Library, the USA. 
group activity; i.e. the activity of the small group with an external status. In the context of functioning of the small group with external status, the border guard officer is the official leader for the subordinate personnel. That is why the formation and the further development of the organizational abilities of the border guard officers is necessary for the proper performing moral and psychological support of the subordinate personnel. It goes without saying in the case of not having the essential commanding abilities; any border guard officer is not ready for carrying out the professionally-oriented interaction. A border guard officer has to be able of: 1) choosing the most optimal option in the specific situation of professional interaction and 2) providing the proper psychological support for the subordinate personnel professional activities.

Self-organization of an officer as a unit leader is one of the most important elements of his organizational activities as well as in the context of his professional activities as a whole. In this case, the important role in the process of self-organization is the ability to organize his personal mental abilities and processes, as well as the ability to manage them. In the process of implementing moral and psychological support for the professional activities of the subordinate personnel, the officer's ability to focus her/his attention on the certain types of the psychological support, including the conditions of the considerable psychological stress, to switch one's attention from one type of the professional activity to another, the ability to activate and mobilize all the mental abilities is extremely important, including their implementing in the extreme conditions.

Taking into the consideration the fact that the border guard officer is responsible for carrying out the proper moral and psychological support of the professional activity of the subordinate personnel around the clock and systematically, it is absolutely important to be able of organizing organize his her activities properly and making decisions in the case of changing the situation. In this context we emphasize the importance of the order and sequence of the officer's performance while carrying out duties in accordance with a defined strategy, as well as the ability to rationally alternate between different activities, taking into account the principle of reasonable sufficiency.

In the investigation we have taken into our account the fact that the specific abilities that are of interest include not only those which 
may be reflected in general abilities, and also some special skills and knowledge. The organizational abilities are the specific abilities; they are more directly related to behaviours in the group and hence exert a more powerful effect upon group process3 (Shaw, 1976, p. 173).

The study results indicate that the ability to organize the moral and psychological support of professional activity of the State Border Guard Service of Ukraine personnel is a set of the individual psychological features of the development of the certain psychomotor and mental processes and properties of a border guard officer, which determine the speed, strength and relative ease of his organizational activities. The organizational abilities are formed in the process of officers' professional activity and ensure the success of the organizational work within the framework of effective group dynamics.

The professional activity of border guard officers involves, along with solution of a number of tasks of performing complex organizational functions, including organization of moral and psychological support for the professional activity of subordinate stuff these functions are not limited to the management activitie ${ }^{4}$. Among them there are three main groups: self-organization, organization of professional activities of personnel and general organization of the operation of the subordinate unit as a small group with the specific external status.

Taking into account the above mentioned facts the program of the purposeful development of organizational abilities of students and cadets of the NASBGSU (has been worked out on the basis of a complex approach to the professional suitability, which combines the analysis of the social factors of the professional development (organizational, knowledge, skills, motives) and individual's psychophysiological characteristics.

The border guard officer's organizational activity is a multi-aspect and extremely complex part of the professional activity, which

${ }^{3}$ Shaw E. (1976). Marvin Group Dynamics. The Psychology of Small Group. McGraw-Hill, the USA.

4 Education Psychology (2000). Effective Teaching, Effective Learning. Krtochwill Thomas R., Cook Jan Littlefield, Travers John F. Third Edition. Mc GrowHill Higher Education, the USA. 
indicates that the organizational abilities are the important precondition for the professional suitability. This point of view is confirmed by the theoretical analysis and empirical data of our study. One of the effective ways of improving professional training of students and cadets of the NASBGSU is psychological comprehend of the mechanisms of the learning educational material, as well as revealing the role of general and special organizational abilities, their formation and development, ways of forming skills and aptitude of one's professional activity. According to the program it is envisaged the development of the organizational abilities in the training process in the conditions of the higher military educational establishment. While working out the program the results of the analysis of the academic courses taught in all areas of the professional training of border guards at the NASBGSU according to the levels of higher education were taken into account. They indicate that physical training, fire and tactical-specific training are of the particular importance for the development of students and cadets' organizational abilities.

Physical training is one of the main courses which is conducted at the Department of Physical Training and Personal Security where students and cadets have the course of Physical Education at the first Bachelor's degree level the course of Physical Training at the second Master's degree level. Physical exercises significantly affect development of the volitional character traits (the level of willpower as a complex indicator of volitional organization), self-organization, determination, perseverance, self-control, increasing the level of independence (including the problem-solving ability); improvement of value-meaning organization of personality; formation of mental and psychic stability, self-control and the ability to control one's emotional state), as well as necessary for improving attention stability.

"Fire Training", "Tactical Fire Training" (for specialization 'officer of the mobile units') courses are taught at the first Bachelor's degree level; "Fire Training Organization" course - at the second Master's degree level at the Department of Fire and Tactical Special Training.

The main purpose of these courses is the formation of the essential level of the professional competencies of border guard officers to perform the tasks particularly the necessary intellectual and moral qualities 
(memory, attention, will, perseverance, organization, responsibility, determination, self-control, neuro-psychic stability, etc.).

The important prerequisite for the formation of the organizational abilities of students and cadets is their active involvement into the activities of formative, developmental and educational influence, which is provided at all the training courses in the system of professional training. The evidence has confirmed that all these measures of educational influence contribute to the development of the volitional organization of personality of students and cadets, forming such personality traits as self-control, perseverance, independence, responsibility, determination, organization, endurance and many others.

The program is based on the special system of the organizational abilities formation and development at the different stages of professional development.

\section{Program of Formation and Development of the Organizational Abilities of Students and Cadets of the NASBGSU}

The purpose of the program is to ensure the determined and comprehensive development of personal qualities that are part of the organizational capabilities and necessary for the proper implementation of the moral and psychological support of the professional activities of the subordinate personnel by the border guard officer. According to the purpose of the program there are two tasks to be solved namely: 1) development of the general abilities and 2) development of the specific organizational abilities of students and cadets of the 1 NASBGSU.

While working out the program we have taken into our account the fact that the main qualities of the organizational abilities related to the emotional and willful sphere of personality of the border guard officers are the following:

- demanding attitude, perseverance (officers who have the proper level of these qualities are characterized by courage, flexibility in communication, using the various forms of prompting, from jokes to orders, the individual approach to the personnel depending on the permanent and temporary mental characteristics (1); the ability to motivate subordinate personnel, to activate their professional activities and create a positive atmosphere in the unit; 
- critical approach, self-criticism, personality determination the ability to analyze deviations from the norm of the professional activity and behavior of other people, which is expressed in independence while conducting a critical analysis together with the personnel of the particular unit; logical and reasonable approach to critical remarks, courage, and respect for subordinates, kind and amiable attitude;

- neuro-psychic stability - the ability to withstand the strong negative emotional influences that may cause high mental stress. The importance of this factor is due to extraordinary emotional intensity of border guard officers' professional management, which activates the role of the emotional regulatory mechanisms in the structure of a leader's personality especially in the case of the extraordinary situations that force the leader to find the optimal solutions on problem-solving aspects on border protection;

- practical psychological mind (intelligence) - the ability of an officer to distribute tasks depending on the individual characteristics and abilities of the personnel;

- ability to regulate one's mental state depending on the conditions of professional activity and taking into account the dynamics of group processes in the unit, the peculiarities of relationships between subordinate staff during the organization, support and control of the professional activity.

The following components have been taken into our consideration within the investigation of the special organizational skills:

- communication skills of the manager (personal quality that manifests itself in the ability to make contacts, communicate). In the study, we considered that the communicative abilities of the leader influence the degree of success of the use of verbal and non-verbal communication;

- psychological acumen - quick understanding of psychological characteristics and condition of other people, the ability to remember people and their actions, a tendency to psychological analysis of the behavior and actions of subordinate personnel as well as their own behavior, deep faith and belief in the strength, capability and capabilities of the subordinate personnel;

- psychological tact - the ability to influence other people, to communicate with them taking into account one's individual, age 
and gender characteristics; the ability to deal with difficult and embarrassing situations carefully and without doing or saying anything that will annoy or upset other people ${ }^{5}$ ( Hornby, 2005 p. 1561).

- inclination to organizational (managerial) activity, (spontaneous, independent role in organizational activity; ability to take on the role of organizer and responsibility for the activity of personnel in difficult and unfavorable conditions;

- independence, self-control - the ability to engage in organizing activities, the need to carry out organizational activities and constant willingness to take on it, receiving positive emotions from its implementation.

The first part of the program, based on the practical training, consists of two blocks: 1) the development of typological characteristics of nervous system and volitional organization of one's personality; 2) the development of the cognitive sphere of one's personality.

The exercises of the first block are multi-purpose; they are aimed at forming both - the typological and volitional qualities. At the same time this process is carried out in three directions: 1) mastering the methodology of self-regulation and selfmanagement; 2) solving simulated professionally oriented problematic tasks; 3) training of psychological stability. The total number of physical training hours (315), firing training hours (362) and tactical training (142) hours is 819 .

The second part of the program consists of three blocks and promotes the development of certain psychological properties of the border guard officer's personality: 1) block I of the program (for border guard officers) is presented by "Managerial course for increasing the level of managerial competence of border guard officers; 2) block II was designed for students of the Faculty of Leadership Training and 3) block III was worked out for the cadets of all the faculties.

5 Hornby A. S. (2005). Oxford Advanced Learner's Dictionary, Oxford University Press, the Seventh Edition. 


\section{Verification of the Program Effectiveness}

In order to check the effectiveness of the program we conducted the study of the level of the organizational abilities development of the personnel of the NA of SBGSU at the end of 2017.

252 officers, 125 students of the faculty of management training, 1061 cadets of all the faculties of the academy were involved into the experiment. The results of the survey are presented in Table 1.

Table 1

\section{Level of Organizational Abilities Formation} of the NASBGS Personnel (2017)

\begin{tabular}{|c|c|c|c|c|c|c|c|c|c|}
\hline \multirow{3}{*}{$\begin{array}{l}3 \\
\frac{3}{\bar{n}} \\
\text { 崶 }\end{array}$} & \multirow{3}{*}{ 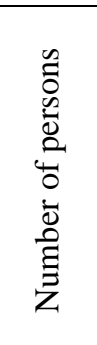 } & \multirow{3}{*}{ 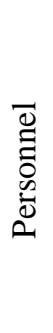 } & \multicolumn{6}{|c|}{$\begin{array}{c}\text { Number (\%) of persons at the appropriate } \\
\text { level }\end{array}$} & \multirow{3}{*}{ 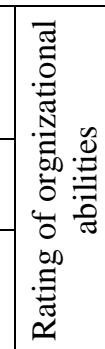 } \\
\hline & & & \multicolumn{2}{|c|}{$\begin{array}{c}\text { sufficient } \\
\geq 0,61\end{array}$} & \multicolumn{2}{|c|}{$\begin{array}{l}\text { average } \\
0,41-0,6\end{array}$} & \multicolumn{2}{|c|}{$\begin{array}{l}\text { low } \\
\leq 0,4\end{array}$} & \\
\hline & & & number & $\%$ & number & $\%$ & number & $\%$ & \\
\hline 1 & 28 & \multirow{6}{*}{ 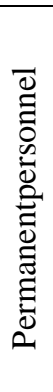 } & 21 & 75,00 & 7 & 25,00 & 0 & 0,0 & 0,76 \\
\hline 2 & 108 & & 95 & 87,96 & 10 & 9,26 & 3 & 2,78 & 0,80 \\
\hline 3 & 52 & & 39 & 75,00 & 12 & 23,08 & 1 & 1,92 & 0,76 \\
\hline 4 & 25 & & 18 & 72,00 & 7 & 28,00 & 0 & 0,00 & 0,75 \\
\hline 5 & 39 & & 31 & 79,49 & 7 & 17,95 & 1 & 2,56 & 0,77 \\
\hline otal & 252 & & 204 & 80,96 & 43 & 17,06 & 5 & 1,98 & 0,78 \\
\hline 1 & 125 & \multirow{6}{*}{ 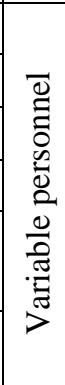 } & 111 & 88,89 & 14 & 11,22 & 0 & 0,0 & 0,81 \\
\hline 2 & 412 & & 156 & 37,87 & 200 & 48,54 & 56 & 13,59 & 0,59 \\
\hline 3 & 353 & & 194 & 54,96 & 99 & 28,04 & 60 & 17,00 & 0,65 \\
\hline 4 & 159 & & 94 & 59,12 & 37 & 23,27 & 28 & 17,61 & 0,66 \\
\hline 5 & 137 & & 89 & 64,96 & 14 & 10,22 & 34 & 24,82 & 0,66 \\
\hline & $1061 *$ & & $533^{*}$ & $50,24 *$ & $350 *$ & $32,98^{*}$ & $178^{*}$ & $16,78^{*}$ & $0,63 *$ \\
\hline
\end{tabular}


1. The data of the final line in the table is formed in relation to the faculties (only for the cadets). The comparison of the obtained results with the previous ones proved that $80.96 \%$ of the interviewed respondents had the developed organizational abilities at the proper level, which is almost $40 \%$ more than the previous results. As for the cadets there is $26.39 \%$ increase of the level of the organizational abilities. The moderate increase may be due to the fact that the 2014 survey included only senior cadets who have more experience in the organizational activity than junior cadets. The statistical verification was performed using Pearson's nonparametric criterion $\chi 2^{6}$ (Sidorenko, 2000, p. 113), the statistical hypotheses are constructed as follows:

1) the basic hypothesis: $H_{0}$ - the shares of the cadets who have the appropriate level of the organizational abilities do not differ among the respondents of 2014 and 2017;

2) the alternative hypothesis: $H_{1}$ - the share of cadets with the appropriate level of organizational skills is significantly different among the respondents of 2014 and 2017.

The empirical value of the criterion was calculated using a specially created software product in EXCEL. We then compared it with the critical values for degrees of freedom

$$
\begin{gathered}
v=(k-1) \cdot(c-1)=(3-1) \cdot(2-1)=2 . \\
\chi_{\kappa p}^{2}= \begin{cases}5,991 & (p \leq 0,05) \\
9,210 & (p \leq 0,01)\end{cases}
\end{gathered}
$$

It should be noted that all the limitations of this criterion have been met: the sample size is large enough; the number of character signs (levels) is greater than

The calculated value of the criterion (Table 2) turned out to be higher than the critical one for all samples, which allows us to accept the statistical hypothesis $H_{1}$ about the significance of differences between the groups of respondents at least 0.01 (probability of error does not exceed 1\%). This, in turn, indicates the effectiveness of the suggested method.

${ }^{6}$ Sidorenko E. V. (2000). Metodyi matematicheskoy obrabotki v psihologii [Methods of Mathematical Processing in Psychology]. SPb.: Rech Publ. [in Russian]. 
Table 2

Dynamics of organizational skills formation (statistical check)

\begin{tabular}{|c|c|c|c|c|c|}
\hline \multirow[t]{2}{*}{ Faculty } & \multirow{2}{*}{$\begin{array}{c}\text { Number of people } \\
\text { at the appropriate } \\
\text { level }\end{array}$} & \multicolumn{2}{|c|}{ Permanentpersonnel } & \multicolumn{2}{|c|}{$\begin{array}{c}\text { Variable } \\
\text { personnel }\end{array}$} \\
\hline & & 2014 & 2017 & 2014 & 2017 \\
\hline \multirow{3}{*}{1} & Sufficient $\geq 0,61$ & 11 & 21 & 24 & 111 \\
\hline & Average $0,41-0,6$ & 20 & 7 & 13 & 14 \\
\hline & Low $\leq 0,4$ & 1 & 0 & 1 & 0 \\
\hline \multicolumn{2}{|c|}{ Empirical value of criterion $\chi_{e n n}^{2}$} & \multicolumn{2}{|c|}{10,1628} & \multicolumn{2}{|c|}{14,918} \\
\hline \multirow{3}{*}{2} & Sufficient $\geq 0,61$ & 59 & 95 & 20 & 156 \\
\hline & Average $0,41-0,6$ & 60 & 10 & 67 & 200 \\
\hline & Low $\leq 0,4$ & 4 & 3 & 25 & 56 \\
\hline \multicolumn{2}{|c|}{ Empirical value of criterion $\chi_{\text {eun }}^{2}$} & \multicolumn{2}{|c|}{43,482} & \multicolumn{2}{|c|}{17,0335} \\
\hline \multirow{3}{*}{3} & $\begin{array}{l}\text { Sufficient } \\
\geq 0,61\end{array}$ & 28 & 39 & 21 & 194 \\
\hline & $\begin{array}{l}\text { Average } \\
0,41-0,6\end{array}$ & 33 & 12 & 31 & 99 \\
\hline & Low $\leq 0,4$ & 2 & 1 & 8 & 60 \\
\hline \multicolumn{2}{|c|}{ Empiricalvalueofcriterion $\chi_{e n n}^{2}$} & \multicolumn{2}{|c|}{10,9877} & \multicolumn{2}{|c|}{13,4324} \\
\hline \multirow{3}{*}{4} & Sufficient $\geq 0,61$ & 12 & 18 & 8 & 94 \\
\hline & Average $0,41-0,6$ & 24 & 7 & 16 & 37 \\
\hline & Low $\leq 0,4$ & 2 & 0 & 6 & 28 \\
\hline \multicolumn{2}{|r|}{$\chi_{e n n}^{2}$} & \multicolumn{2}{|c|}{10,2777} & \multicolumn{2}{|c|}{13,1393} \\
\hline \multirow{3}{*}{5} & Sufficient $\geq 0,61$ & 13 & 31 & 3 & 89 \\
\hline & Average $0,41-0,6$ & 22 & 7 & 10 & 14 \\
\hline & Low $\leq 0,4$ & 2 & 1 & 3 & 34 \\
\hline \multicolumn{2}{|c|}{ Empiricalvalueofcriterion $\chi_{e n n}^{2}$} & \multicolumn{2}{|c|}{15,4136} & \multicolumn{2}{|c|}{30,2708} \\
\hline \multirow{3}{*}{$\begin{array}{l}\text { Consoli- } \\
\text { dated } \\
\text { data }\end{array}$} & Sufficient $\geq 0,61$ & 123 & 204 & 52 & 533 \\
\hline & Average $0,41-0,6$ & 159 & 43 & 124 & 350 \\
\hline & Low $\leq 0,4$ & 11 & 5 & 42 & 178 \\
\hline \multicolumn{2}{|c|}{ Empiricalvalueofcriterion $\chi_{\text {enn }}^{2}$} & \multicolumn{2}{|c|}{86,3323} & \multicolumn{2}{|c|}{56,0283} \\
\hline
\end{tabular}

In order to check whether changes in the formation of the special organizational abilities of the respondents took place, the specialists of the department of psychological support conducted the additional survey of the respondents. The results of which are presented in Table 3. 
Table 3

Level of Special Organizational Abilities Formation of NASBGS personnel (2017)

\begin{tabular}{|c|c|c|c|c|c|c|}
\hline \multirow[b]{2}{*}{ 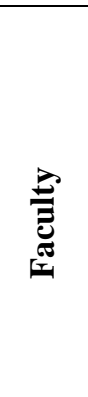 } & \multirow[b]{2}{*}{ 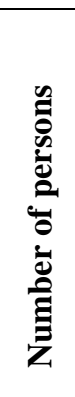 } & \multicolumn{2}{|c|}{ Permanent staff } & \multirow[b]{2}{*}{ 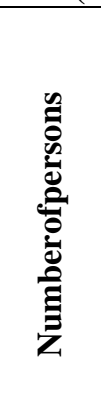 } & \multicolumn{2}{|c|}{ Variablestaff } \\
\hline & & 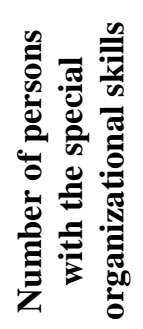 & $2^{2}$ & & 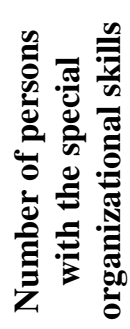 & $a^{2}$ \\
\hline 1 & 28 & 5 & 17,86 & 125 & 8 & 6,4 \\
\hline 2 & 108 & 10 & 9,26 & 412 & 37 & 8,98 \\
\hline 3 & 52 & 9 & 17,31 & 353 & 28 & 7,93 \\
\hline 4 & 25 & 7 & 28,0 & 159 & 23 & 14,46 \\
\hline 5 & 39 & 8 & 20,51 & 137 & 28 & 20,44 \\
\hline Total & 252 & 39 & 15,48 & $1061 *$ & $116^{*}$ & $10,93 *$ \\
\hline
\end{tabular}

The final line data for the variable personnel is given only for the cadets of all the faculties.

The results of the analysis of these figures shows that the proportion of the respondents with the special (organizational) abilities has increased from $6.48 \%$ to $15.48 \%$ among permanent staff, and from $3.67 \%$ to $10.93 \%$ among cadets.

The statistical check of the significance of the difference was carried out by means of the nonparametric criterion $\varphi^{*}$, namely by means of angular transformation of Fisher ${ }^{7}$ (Sidorenko, 2000, p. 158), the statistical hypotheses are constructed as follows:

- The basic hypothesis: $H_{0}$ - the proportions of the persons having the special organizational abilities for the specified groups do not differ;

- The competing hypothesis: $H_{1}$ - the proportions of persons with the special organizational skills for these groups differs significantly.

7 Sidorenko E. V. (2000). Metodyi matematicheskoy obrabotki v psihologii [Methods of Mathematical Processing in Psychology]. SPb.: Rech Publ. [in Russian]. 
The empirical value of the criterion is calculated by the formula

$$
\varphi_{\text {eмn }}^{*}=\left(\varphi_{1}-\varphi_{2}\right) \sqrt{\frac{n_{1} \cdot n_{2}}{n_{1}+n_{2}}},
$$

where $\varphi 1$ is the angle corresponding to the larger percentage; $\varphi 2$ is the angle of the smaller percentage; $\mathrm{n} 1, \mathrm{n} 2$ is the number of people in groups.

The empirical value of the criterion was compared with the critical values of the corresponding level of statistical significance:

$$
\varphi_{\kappa p}^{*}=\left\{\begin{array}{l}
1,64(p \leq 0,05) \\
2,31(p \leq 0,01)
\end{array} .\right.
$$

The calculated empirical values (Table 6.7) of the criterion made it possible to confirm the validity of the competing statistical hypothesis regarding statistically significant differences between the respondents of the years 2014 and 2017.

Table 4

\section{Dynamics in Change of the Special Organizational Abilities}

\begin{tabular}{|c|c|c|c|c|c|c|}
\hline \multirow[b]{2}{*}{ 营 } & \multirow[b]{2}{*}{ 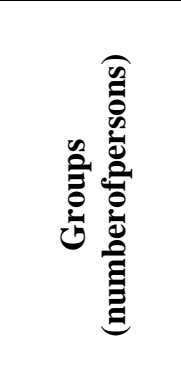 } & \multicolumn{2}{|c|}{ Permanent staff } & \multirow[b]{2}{*}{ 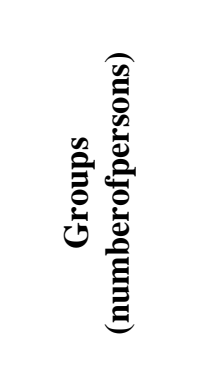 } & \multicolumn{2}{|c|}{ Variable staff } \\
\hline & & 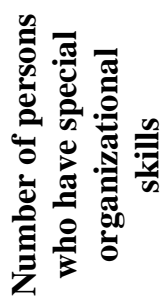 & $\begin{array}{l}\frac{1}{\pi} \\
0^{\circ} \\
0^{\circ} \\
0^{\circ}\end{array}$ & & 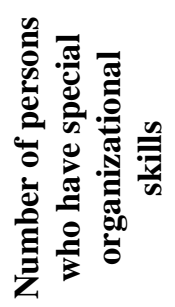 & 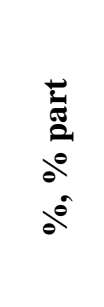 \\
\hline 1 & 2 & 3 & 4 & 5 & 6 & 7 \\
\hline \multirow{4}{*}{1} & \multirow{2}{*}{$\begin{array}{c}2014 \\
\text { (32 persons) }\end{array}$} & & $9,37 \%$ & \multirow{2}{*}{$\begin{array}{c}2014 \\
\text { (38 persons) }\end{array}$} & \multirow{2}{*}{1} & $2,63 \%$ \\
\hline & & & 0,623 & & & 0,324 \\
\hline & \multirow{2}{*}{$\begin{array}{c}2017 \\
\text { (28 persons) }\end{array}$} & & $17,86 \%$ & \multirow{2}{*}{$\begin{array}{c}2017 \\
\text { (125 persons) }\end{array}$} & \multirow{2}{*}{8} & $6,4 \%$ \\
\hline & & & 0,874 & & & 0,512 \\
\hline & $\varphi_{\text {enn }}^{*}$ & \multicolumn{2}{|c|}{$0,970 \rho \leq 0,10$} & $\varphi_{\text {emn }}^{*}$ & \multicolumn{2}{|c|}{$1,015 \rho \leq 0,10$} \\
\hline
\end{tabular}
Formation (statistical check) 
End of Table 4

\begin{tabular}{|c|c|c|c|c|c|c|}
\hline 1 & 2 & 3 & 4 & 5 & 6 & 7 \\
\hline \multirow{4}{*}{2} & & \multirow{2}{*}{4} & $3,25 \%$ & \multirow{2}{*}{$\begin{array}{c}2014 \\
\text { (112 persons) }\end{array}$} & \multirow{2}{*}{5} & $4,46 \%$ \\
\hline & $\begin{array}{c}2014 \\
\text { (123 persons) }\end{array}$ & & 0,365 & & & 0,428 \\
\hline & \multirow{2}{*}{$\begin{array}{c}2017 \\
\text { (108 persons) }\end{array}$} & \multirow{2}{*}{10} & $9,26 \%$ & \multirow{2}{*}{$\begin{array}{c}2017 \\
\text { (412 persons) }\end{array}$} & \multirow{2}{*}{37} & $8,98 \%$ \\
\hline & & & 0,620 & & & 0,606 \\
\hline & $\varphi_{\text {exn }}^{*}$ & 1,93 & 0,026 & $\varphi_{\text {enn }}^{*}$ & \multicolumn{2}{|r|}{0,047} \\
\hline \multirow{4}{*}{3} & \multirow{2}{*}{$\begin{array}{l}2014 \\
\text { (63 persons) }\end{array}$} & \multirow{2}{*}{4} & $6,35 \%$ & \multirow{2}{*}{$\begin{array}{c}2014 \\
(60 \text { persons })\end{array}$} & \multirow{2}{*}{1} & $1,67 \%$ \\
\hline & & & 0,512 & & & 0,262 \\
\hline & \multirow{2}{*}{$\begin{array}{c}2017 \\
\text { (52 persons) }\end{array}$} & \multirow{2}{*}{9} & $17,31 \%$ & \multirow{2}{*}{$\begin{array}{c}2017 \\
\text { (353 persons) }\end{array}$} & \multirow{2}{*}{28} & $7,93 \%$ \\
\hline & & & 0,858 & & & 0,570 \\
\hline & $\varphi_{\text {exn }}^{*}$ & \multicolumn{2}{|c|}{$\leq 0,032$} & $\varphi_{\text {eMn }}^{*}$ & \multicolumn{2}{|r|}{0,013} \\
\hline \multirow{4}{*}{4} & \multirow{2}{*}{$\begin{array}{c}2014 \\
\text { (38 persons) }\end{array}$} & \multirow{2}{*}{5} & $13,16 \%$ & 2014 & , & $3,33 \%$ \\
\hline & & & 0,744 & (30 persons) & 1 & 0,365 \\
\hline & 2017 & & $28,0 \%$ & 2017 & ? & $14,46 \%$ \\
\hline & (25 persons) & 1 & 1,115 & (159 persons) & 25 & 0,781 \\
\hline & $\varphi_{e \text { enn }}^{*}$ & 1,44 & 0,075 & $\varphi_{\text {eмn }}^{*}$ & 2,09 & 0,018 \\
\hline & 2014 & 0 & $8,11 \%$ & 2014 & 1 & $6,25 \%$ \\
\hline & (37 persons) & $J$ & 0,577 & (16 persons) & 1 & 0,507 \\
\hline$J$ & 2017 & Q & $20,51 \%$ & 2017 & 20 & $20,44 \%$ \\
\hline & (39 persons) & 0 & 0,940 & (137 persons) & 20 & 0,937 \\
\hline & $\varphi_{\text {enn }}^{*}$ & 1,58 & 0,057 & $\varphi_{\text {eмn }}^{*}$ & 1,63 & 0,053 \\
\hline & 2014 & 10 & $6,48 \%$ & 2014 & 0 & $3,67 \%$ \\
\hline$\frac{\pi}{\partial}$ & (293 persons) & 19 & 0,516 & (218 persons) & 8 & 0,387 \\
\hline : & 2017 & & $15,48 \%$ & 2017 & & $10,93 \%$ \\
\hline ठ̃ & (252 persons) & & 0,809 & persons) & & 0,673 \\
\hline & $\varphi_{\text {eqn }}^{*}$ & 3,41 & 0,001 & $\varphi_{\text {eмn }}^{*}$ & 3,85 & 0,001 \\
\hline
\end{tabular}

The most significant changes were observed among the respondents of the $1^{\text {st }}$ Faculty, where at the beginning of the study, in 2014 the highest level of the organizational abilities was determined. 
The significance of the changes for each faculty varies within 5-7\% of the error, while for the consolidated data the significance is undeniable; the probability of error is less than $1 \%$.

It was also verified that statistically significant changes in the management styles among the permanent personnel (Table 1) and the stress resistance level and adaptive capacity among the variable personnel (Table 5).

Table 5

Dynamics of Changes in Management Styles Among Permanent NASBGS Personnel (2017)

\begin{tabular}{|c|c|c|c|c|c|c|c|c|c|c|c|}
\hline \multirow{3}{*}{ 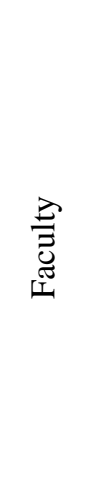 } & \multirow{3}{*}{ 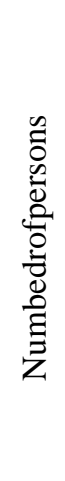 } & \multicolumn{10}{|c|}{ Number (\%) of persons with the stated management style } \\
\hline & & \multicolumn{2}{|c|}{ 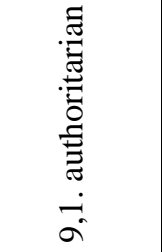 } & \multicolumn{2}{|c|}{ 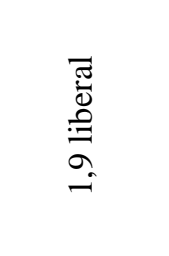 } & \multicolumn{2}{|c|}{ 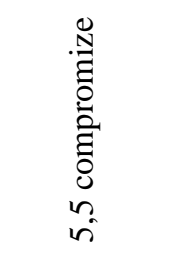 } & \multicolumn{2}{|c|}{ 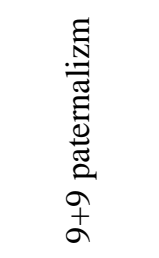 } & \multicolumn{2}{|c|}{ 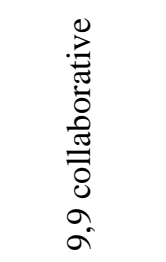 } \\
\hline & & 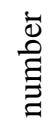 & de & $\begin{array}{l}\overline{\bar{\Xi}} \\
\text { है } \\
\text { 吾 }\end{array}$ & $d^{0}$ & $\begin{array}{l}\overline{\mathrm{D}} \\
\overline{\mathrm{E}} \\
\mathrm{\Xi}\end{array}$ & de & 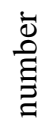 & de & 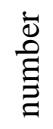 & de \\
\hline 1 & 28 & 5 & 17,86 & 3 & 10,71 & 7 & 25 & 6 & 21,43 & 7 & 25,0 \\
\hline 2 & 108 & 7 & 6,48 & 14 & 12,96 & 18 & 16,67 & 26 & 24,07 & 43 & 39,82 \\
\hline 3 & 52 & 6 & 11,54 & 7 & 13,46 & 8 & 15,39 & 7 & 13,46 & 24 & 46,15 \\
\hline 4 & 25 & 3 & 12,0 & 6 & 24,0 & 9 & 36,0 & 3 & 12,0 & 4 & 16,0 \\
\hline 5 & 39 & 8 & 20,51 & 5 & 12,82 & 11 & 28,21 & 7 & 17,95 & 8 & 20,51 \\
\hline Total & 252 & 29 & 11,51 & 35 & 13,89 & 53 & 21,03 & 49 & 19,44 & 86 & 34,13 \\
\hline
\end{tabular}

The statistical verification was performed using the same nonparametric criterion $\varphi^{*}-$ Fisher angular transformation ${ }^{8}$ (Sidorenko, 2000, p. 158). The statistical hypotheses are formulated as follows:

${ }^{8}$ Sidorenko E. V. (2000). Metodyi matematicheskoy obrabotki v psihologii [Methods of Mathematical Processing in Psychology]. SPb.: Rech Publ. [in Russian]. 
The basic hypothesis: $H_{0}$ - the proportions of persons having the appropriate leadership style do not differ for the identified groups;

The competing hypothesis: $H_{1}$ - the proportions of persons having the appropriate leadership style differ significantly for these groups.

The empirical value of the criterion was calculated by the formula (1.2) and then we compared it with the critical values of the corresponding level of statistical significance (1.3). Further according to Table XIII9 (Sidorenko, 2000, p. 332) the level of statistical significance in the case of the least significant differences was determined.

The empirical values of the criterion (presented in Table 6) confirm the validity of the competing statistical hypotheses concerning the differences between the 2014 and 2017 group respondents.

Table 6

\section{Dynamics of Change in Leadership Styles (Statistical Verification)}

\begin{tabular}{|c|c|c|c|c|c|c|}
\hline 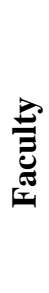 & 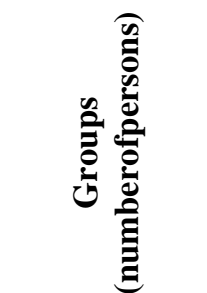 & 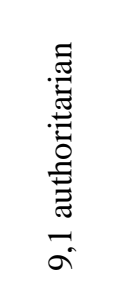 & 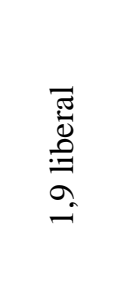 & 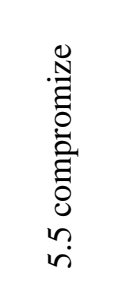 & 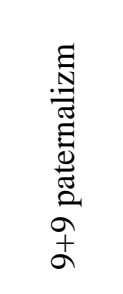 & 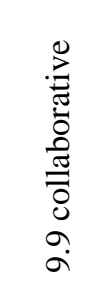 \\
\hline 1 & 2 & 3 & 4 & 5 & 6 & 7 \\
\hline \multirow{4}{*}{1} & \multirow{2}{*}{$\begin{array}{c}2014 \\
\text { (32 persons) }\end{array}$} & 12 & 3 & 4 & 10 & 3 \\
\hline & & $37,5 \%$ & $9,38 \%$ & $12,5 \%$ & $31,25 \%$ & $9,38 \%$ \\
\hline & \multirow{2}{*}{$\begin{array}{c}2017 \\
\text { (28 persons) }\end{array}$} & 5 & 3 & 7 & 6 & 7 \\
\hline & & $17,86 \%$ & $10,71 \%$ & $25 \%$ & $21,43 \%$ & $25 \%$ \\
\hline \multicolumn{2}{|c|}{$\varphi_{\text {exn }}^{*}$} & 1,72 & 0,166 & 2,82 & $\mathbf{0 , 8 7}$ & 1,64 \\
\hline \multicolumn{2}{|c|}{$\rho \leq$} & 0,043 & - & 0,001 & - & 0,050 \\
\hline \multirow{2}{*}{2} & \multirow{2}{*}{$\begin{array}{c}2014 \\
\text { (123 persons) }\end{array}$} & 21 & 18 & 14 & 41 & 29 \\
\hline & & $17,07 \%$ & $14,63 \%$ & $11,38 \%$ & $33,33 \%$ & $23,57 \%$ \\
\hline
\end{tabular}

9 Sidorenko E. V. (2000). Metodyi matematicheskoy obrabotki v psihologii [Methods of Mathematical Processing in Psychology]. SPb.: Rech Publ. [in Russian]. 
End of Table 6

\begin{tabular}{|c|c|c|c|c|c|c|}
\hline \multirow[t]{3}{*}{1} & 2 & 3 & 4 & 5 & 6 & 7 \\
\hline & \multirow{2}{*}{$\begin{array}{c}2017 \\
\text { (108 persons) }\end{array}$} & 7 & 14 & 18 & 26 & 43 \\
\hline & & $6,48 \%$ & $12,96 \%$ & $16,67 \%$ & $24,07 \%$ & $39,82 \%$ \\
\hline \multicolumn{2}{|c|}{$\varphi_{\text {enn }}^{*}$} & 2,55 & $\mathbf{0 , 3 5}$ & 1,16 & 1,55 & 2,68 \\
\hline \multicolumn{2}{|c|}{$\rho \leq$} & 0,004 & - & - & 0,061 & 0,003 \\
\hline \multirow{4}{*}{3} & \multirow{2}{*}{$\begin{array}{c}2014 \\
\text { (63 persons) }\end{array}$} & 13 & 7 & 10 & 15 & 18 \\
\hline & & $20,64 \%$ & $11,11 \%$ & $15,87 \%$ & $23,81 \%$ & $28,57 \%$ \\
\hline & \multirow{2}{*}{$\begin{array}{c}2017 \\
\text { (52 persons) }\end{array}$} & 6 & 7 & 8 & 7 & 24 \\
\hline & & $11,54 \%$ & $13,46 \%$ & $15,39 \%$ & $13,46 \%$ & $46,15 \%$ \\
\hline \multicolumn{2}{|c|}{$\varphi_{\text {enn }}^{*}$} & 1,33 & 0,39 & $\mathbf{0 , 0 7}$ & 1,42 & 1,95 \\
\hline \multicolumn{2}{|c|}{$\rho \leq$} & 0,092 & - & - & 0,078 & 0,026 \\
\hline \multirow{4}{*}{4} & \multirow{2}{*}{$\begin{array}{c}2014 \\
\text { (38 persons) }\end{array}$} & 10 & 8 & 5 & 12 & 3 \\
\hline & & $26,32 \%$ & $21,05 \%$ & $13,16 \%$ & $31,58 \%$ & $7,89 \%$ \\
\hline & \multirow{2}{*}{$\begin{array}{c}2017 \\
(25 \text { persons })\end{array}$} & 3 & 6 & 9 & 3 & 4 \\
\hline & & $12,0 \%$ & $24,0 \%$ & $36,0 \%$ & $12,0 \%$ & $16,0 \%$ \\
\hline \multicolumn{2}{|c|}{$\varphi_{\text {enn }}^{*}$} & 1,44 & 0,27 & 2,11 & 1,89 & $\mathbf{0 , 9 8}$ \\
\hline \multicolumn{2}{|c|}{$\rho \leq$} & 0,075 & - & 0,017 & 0,029 & - \\
\hline \multirow{4}{*}{5} & \multirow{2}{*}{$\begin{array}{c}2014 \\
\text { (37 persons) }\end{array}$} & 13 & 4 & 2 & 15 & 3 \\
\hline & & $35,14 \%$ & $10,81 \%$ & $5,40 \%$ & $40,54 \%$ & $8,11 \%$ \\
\hline & \multirow{2}{*}{$\begin{array}{c}2017 \\
\text { (39 persons) }\end{array}$} & 8 & 5 & 11 & 7 & 8 \\
\hline & & $20,51 \%$ & $12,82 \%$ & $28,2 \%$ & $17,95 \%$ & $20,51 \%$ \\
\hline \multicolumn{2}{|c|}{$\varphi_{\text {enn }}^{*}$} & 1,45 & $\mathbf{0 , 2 7}$ & 2,84 & 2,20 & 1,58 \\
\hline \multicolumn{2}{|c|}{$\rho \leq$} & 0,07 & - & 0,001 & 0,014 & 0,057 \\
\hline \multirow{4}{*}{$\begin{array}{c}\text { Consolidated } \\
\text { data }\end{array}$} & \multirow{2}{*}{$\begin{array}{c}2014(293 \\
\text { persons })\end{array}$} & 69 & 40 & 35 & 93 & 56 \\
\hline & & $23,55 \%$ & $13,65 \%$ & $11,95 \%$ & $31,74 \%$ & $19,11 \%$ \\
\hline & \multirow{2}{*}{$\begin{array}{c}2017(252 \\
\text { persons) }\end{array}$} & 29 & 35 & 53 & 49 & 86 \\
\hline & & $11,51 \%$ & $13,89 \%$ & $21,03 \%$ & $19,44 \%$ & $34,13 \%$ \\
\hline \multicolumn{2}{|c|}{$\varphi_{\text {enn }}^{*}$} & 3,76 & $\mathbf{0 , 1 1}$ & 2,85 & 3,31 & 3,98 \\
\hline \multicolumn{2}{|c|}{$\rho \leq$} & 0,001 & - & 0,001 & 0,001 & 0,001 \\
\hline
\end{tabular}

The empirical criterion values obtained for the consolidated data make it possible to state with the sufficient level of reliability (the error 
probability less than $1 \%$ ) that the statistically significant changes in the leadership styles have occurred among the permanent staff of the NASBGSU (except for the liberal leadership style). The results of the analysis of the data confirm that the authoritarian style of leadership elects a much smaller number of persons: $11.51 \%$, whereas in 2014 this figure was $23.55 \%$. There is significant increase in the proportion of the officers with the collaborative style: from $19.11 \%$ to $34.13 \%$.

The experts from the Psychological Support sub-department of the Human Resources Department also conducted the psycho-diagnostic examination using the multi-level Adaptability Questionnaire at the end of 2017. The total number of 125 officers and 980 cadets were enrolled. The results of the cadets' survey are presented in Table 7. As well as in the previous study, it was found out that all the students of the 1st Faculty were sufficiently emotionally resilient. 81 cadets among the examined ones demonstrated the increased level of regularity and the slightly reduced level of adaptive capacity. The obtained result means that only $8.26 \%$ of cadets may not respond adequately to events in the critical professional situations.

Table 7

Statistical Verification of Respondents' Homogeneity by the Stress Resistance Level

\begin{tabular}{|c|c|c|c|c|}
\hline 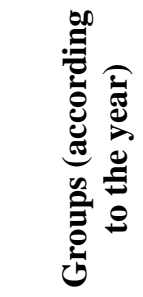 & 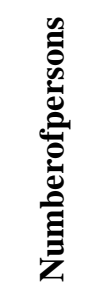 & 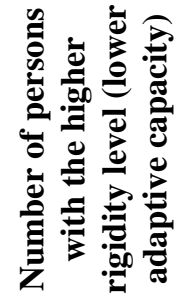 & 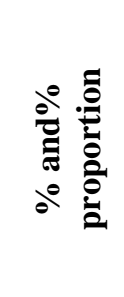 & 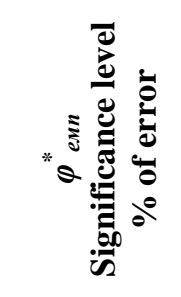 \\
\hline 2014 & 218 & 28 & $\begin{array}{c}12,84 \% \\
0,732 \\
\end{array}$ & \multirow{3}{*}{$\begin{array}{l}\varphi_{\text {eиn }}^{*}=1,98 \\
\rho \leq 0,023 \\
2,3 \%\end{array}$} \\
\hline 2017 & 980 & 81 & $\begin{array}{c}8,26 \% \\
0,584\end{array}$ & \\
\hline Total & 1198 & 109 & & \\
\hline
\end{tabular}

The results of the qualitative analysis of the obtained data show that the purposeful activity resulted in the decrease in the proportion of 
the persons with the reduced levels of stress resistance from $12.84 \%$ to $8.26 \%$.

The empirical value of the criterion was calculated by the formula 1.3:

$$
\varphi_{\text {enn }}^{*}=(0,732-0,584) \sqrt{\frac{218 \cdot 980}{218+980}}=1,98
$$

We compared it with the critical one, which suggested that there were the significant differences between the respondents of the years 2014 and 2017 regarding the number of people with the reduced levels of stress resistance and the proper level of the organizational abilities. The error probability is no more than $2.3 \%$.

\section{CONCLUSION}

The results of the analysis of the problem of the border guard officers' professional competence indicate that the structure of their organizational abilities is determined by the specificity of their professional activity.

Having analyzed the psychological peculiarities of the border guards' professional activity which is performed in the specific and extreme conditions we have determined the components of such activity. They are the following: the cognitive (gnostic), constructive, organizational and communicative components. Each component is typical of performing the certain functions and responsibilities.

The theoretical analysis and empirical data of our study confirmed the point of view that the organizational activity of a border guard officer is a multi-aspect and extremely complex part of individual's professional activity, which indicates that the proper level of the development of the organizational abilities is of vital importance and the essential precondition for the professional suitability of a border guard officer.

The program has been designed for solving two tasks in the system of professional training at the NASBGSU, particularly 1) the development of the general organizational abilities; 2) the formation of the specific organizational abilities of the students and cadets. The proper organizational abilities level of the border guard officer is the 
essential part of the necessary level of his/her professional competence, i.e. to carry out duties up-to-the level.

The first part of the program, which involves the practical training, consists of two blocks: the development of the typological characteristics of the nervous system and volitional organization of one's personality; the development of the personality cognitive sphere. The second part of the program consists of three blocks and contributes to the development of certain psychological properties of the border guard officer's personality.

The results of the analysis of the data obtained as a result of the very realization of the program have shown that $80.96 \%$ of the respondents had the developed organizational abilities at the sufficient level, which is almost $40 \%$ more than the previous results. The proportion of the respondents with the specific abilities has increased from $6.48 \%$ to $15.48 \%$ among the permanent personnel and from $3.67 \%$ to $10.93 \%$ among the cadets. The statistically significant changes in the leadership styles have occurred among the permanent personnel of the academy. Thus, the number of persons who prefer the authoritarian style of leadership decreased from $23.55 \%$ in 2014 to $11.51 \%$ in 2017 . Instead, there is a clear increase in the proportion of the officers with a collaborative style: from $19.11 \%$ to $34.13 \%$.

The results of the investigation of the program of the formation and development of the organizational abilities of students and cadets of the National Academy of State Border Guard Service of Ukraine named after Bohdan Khmelnitskyi have testified its effectiveness.

\section{SUMMARY}

The article deals with revealing the results of the investigation of the program of the purposeful development of the organizational abilities of the students and cadets of the National Academy of the State Border Guard Service of Ukraine named after Bohdan Khmelnitskyi. The program has been worked out on the basis of the results of the theoretical analysis of the border guard officers' professional activity peculiarities and empirical data of the research of the organizational activity as a component of the necessary level of the professional competence. 
The results of the study indicate that the program developed by the author is effective. Therefore, the hypotheses of the study are confirmed, the objective of the study has been achieved.

\section{REFERENCES}

1. Education Psychology (2000). Effective Teaching, Effective Learning. Krtochwill Thomas R., Cook Jan Littlefield, Travers John F. Third Edition. Mc Grow-Hill Higher Education, the USA.

2. Hornby A. S. (2005). Oxford Advanced Learner's Dictionary, Oxford University Press, the Seventh Edition.

3. Shaw E. (1976). Marvin Group Dynamics. The Psychology of Small Group. McGraw-Hill, the USA.

4. Sidorenko E. V. (2000). Metodyi matematicheskoy obrabotki v psihologii [Methods of Mathematical Processing in Psychology]. SPb.: Rech Publ. [in Russian].

5. Volobuieva O. F. (2018). Pro rezultaty anonimnogo opituvanny schodo organizatorskih zdibnostey ofitseriv-prikordonnikiv [About the Results of the Anonymous Questionnaire on the Organizational Abilities of the Border Guard Officers]. Zbirnik naukovih prats Natsionalnoyi akademiyi Derzhavnoyi prikordonnoyi sluzhbi Ukrayini. Seriya: psihologichni nauki-Collection of the Scientific Works of the National Academy of the State Border Guard Service of Ukraine. Series: Psychological Sciences. Hmelnitskiy: NASBGSU Publ. 1(9). 68-85 [in Ukrainian].

6. Willis Dan (2014). Bulletproof Spirit. The First Responder's Essential Resource for Protecting and Healing Mind and Heart. New World Library, the USA.

\section{Information about the author: Olena Volobuieva}

Doctor of Sciences in Psychology, Professor, Academic Research Deputy Rector, National Academy of the State Border Guard Service of Ukraine named after Bohdan Khmelnytskyi 46, Shevchenko str., Khmelnytskyi, 29003, Ukraine ORCID ID: orcid.org/0000-0003-4010-6398 E-mail: helen_volobueva@ukr.net 